\title{
The use of combined techniques: Scottish showers, hot bath and manual techniques in the treatment of migraine headache
}

\author{
Andrei-Cătălin Ionițe ${ }^{1,2}$, Mariana Rotariu², Alexandru Marius Turnea², Gheorghita Andrei ${ }^{3}$
}

\author{
${ }^{1}$ National University of Physical Education and Sport, Str. Constantin Noica, Bucharest, Romania \\ ${ }^{2}$ University of Medicine and Pharmacy "Grigore T. Popa", Str. Universitatii 16, Iasi, Romania \\ ${ }^{3}$ Polytechnic University of Bucharest, Splaiul Independentei 313, Bucharest, Romania
}

Corresponding author: Gheorghita Andrei,

E-mail address: andu_ghe@yahoo.com

\begin{abstract}
Migraines are caused by internal factors (out of which the most important are genetically and physiologically determined) and the external ones, namely, the environment. The most common factor which triggers the migraines is the physiological one. According to some specialized studies, in most cases, it is assumed that migraines are caused by a neuro-vascular disorder. This statement works as a compromise solution for the two theories supported by specialists, which explain the occurrence of migraines: neural mechanisms theory and the theory of vascular origin. Starting from these two theories, we've used Scottish showers, hot baths (37oC) followed by manual drainage of the venous sinuses. The Scottish showers determine the toning of the muscle capillaries. Immersion in warm water for 15 minutes determines vasodilation, along with muscle and mental relaxation. Drainage techniques of venous sinuses operate on the reciprocal tension membranes (RTM), restoring their mobility and improving neuro-vascular disorders. In this research, there were involved 3 subjects, who have taken part in the treatment sessions; they have been monitored and the resulting data has been recorded.
\end{abstract}

Key words: venous sinuses, migraines, dura-mater, Scottish showers, hot bath,

\section{Introduction}

Migraine is characterized by chronic disposition and its specificity consists in the recurring headache of moderate towards severe intensity, associated most often with a number of the autonomic nervous system symptoms. This chronic condition has four stages: prodrome - it occurs before the outbreak of the disease, aura - immediately after the previous episode, the headache, and the postdrome - the effects of the migraine crisis. These stages were classified for the first time in 1988, and in 2004 they were updated by the International Headache Society: migraine without aura, migraine with aura (classical migraine), abdominal migraine, retinal migraine, probable migraine, chronic migraine.

Inside the skull, we can find the reciprocal tension membranes, which are made up of the falx cerebri, the tentorium cerebelli and the pituitary tent. They are made up of intracranial connective tissue obtained through the duplication of the duramater membrane. Inside the reciprocal tension membranes, there are the venous sinuses. Venous sinuses are pipes that collect venous blood inside the skull, and then empty it into the internal jugular veins, which along with the vagus nerve, spinal accessory nerve and glossopharyngeal nerve, protrude from the skull's torn posterior holes level. There are 14 venous sinuses (six odd and four of them even).

\section{Materials and method}

The hypothesis which lays at the basis of this research is the following: we suppose that if we alternate vasoconstriction with vasodilation followed by vasodilation, this will accentuate the results obtained only through the drainage techniques of venous sinuses, thus improving the symptomatology generated by this condition.

Initially, the research consisted in the evaluation of intensity, of spurt frequency and intolerance to noise and light of the migraine before applying the treatment, in order to be able to notice its effects in treating this condition. After applying the treatment, we need to monitor the evolution of patients, and then compare the data obtained.

After outlining the hypothesis, the following tasks have been developed:

- Selecting the subjects

- Establishing the evaluation criteria

- Initial evaluation

- Performing the proposed treatment

- Monitoring and performing the final evaluation

- Analysis and interpretation of the final data.

This research is addressed to athletes who suffer from this condition, but not only, and the selection of subjects was based on the sports activities that they are practicing. Research subjects are young people aged between 20-30 years, both female and male. Two of the subjects were diagnosed by the neurologist, and the third one was not diagnosed by 
the physician, but has the corresponding symptoms of this disease (symptoms corresponding to the first two subjects).

\begin{tabular}{|c|c|c|c|c|c|c|c|c|}
\hline $\begin{array}{l}\text { Nr. } \\
\text { Cri } \\
\text { t. }\end{array}$ & Name & $\begin{array}{l}\text { Gende } \\
\mathrm{r}\end{array}$ & $\begin{array}{l}\mathrm{Ag} \\
\mathrm{e}\end{array}$ & $\begin{array}{l}\text { Weig } \\
\text { ht }\end{array}$ & $\begin{array}{l}\text { Professi } \\
\text { on }\end{array}$ & Diagnosis & $\begin{array}{l}\text { Smok } \\
\text { er }\end{array}$ & $\begin{array}{l}\text { Alcoho } \\
\text { l } \\
\text { consum } \\
\text { er }\end{array}$ \\
\hline 1 & $\begin{array}{l}\text { Subje } \\
\text { ct } 1\end{array}$ & $\begin{array}{l}\text { Fema } \\
\text { le }\end{array}$ & 27 & 67 & Officer & $\begin{array}{l}\text { Cephalic } \\
\text { pain } \\
\text { syndrome } \\
\text { (migraine) }\end{array}$ & No & No \\
\hline 2 & $\begin{array}{l}\text { Subje } \\
\text { ct } 2\end{array}$ & Male & 28 & 98 & $\begin{array}{l}\text { D.P.I. } \\
\text { R }\end{array}$ & $\begin{array}{l}\text { Cephalic } \\
\text { pain } \\
\text { syndrome } \\
\text { (migraine } \\
\text { episodes) }\end{array}$ & No & No \\
\hline 3 & $\begin{array}{l}\text { Subje } \\
\text { ct } 3\end{array}$ & $\begin{array}{l}\text { Fema } \\
\text { le }\end{array}$ & 21 & 54 & $\begin{array}{l}\text { Studen } \\
\mathrm{t} \\
\text { (NCO' } \\
\text { school } \\
\text { ) }\end{array}$ & $\begin{array}{l}\text { Undiagno } \\
\text { sed } \\
\text { (has the } \\
\text { symptoms } \\
\text { of the } \\
\text { migraine) }\end{array}$ & No & No \\
\hline
\end{tabular}

Table no. 1. Introducing the subjects

\section{Description of the study}

This study started with the initial assessment and the inventory of the parameters: pain intensity, spurt frequency within 60 days and intolerance to noise and light. In order to identify these parameters (pain intensity, spurt frequency within 60 days and intolerance to noise and light), we used the scale of pain VAS (Visual Analogue Scale) and the patient had to rate it from 1 to 10 (1 being the lowest value and 10 the maximum).

After the initial assessment and the inventory of the parameters, there have been applied two sessions of treatment to each patient, with a 14-day interval between the two meetings. These 14 days were needed in order to give the body time to activate its recovery memory.

Treatment sessions have begun by using Scottish showers which determine vasoconstriction and vasodilation alternation. The used technique is the upright shower using warm water for 60 seconds (to obtain vasodilation), then immediately cold water for 10 seconds (to obtain vasoconstriction). At the end of of this session, the subject was taken to carry out a warm bath (37oC) for 15 minutes, in order to obtain vasodilation along with muscle and mental relaxation, including mutual tension membranes relaxation, causing the increase of their mobility. After15 minutes, the patient was dry with a towel and shower in room treatment for drainage techniques of venous sinuses.
The standard drainage procedures of venous sinuses for such cases are:

1. The decompression of the $\mathrm{C} 0-\mathrm{C} 1$ area;

2. Release of the temporo-occipital suture;

3. Release of the posterior torn hole;

4. Release each venous sinus as it follows:

- Release of the sigmoidienne sinuses;

- Release of the asterion sinuses (the place where the sigmoidienne sinus is formed, by merging the transverse sinus with the superior petrosal sinus);

- Release of the transverse sinuses;

- Release of the venous sinuses confluence (consisting of the superior sagittal sinus, transverse sinuses and right sinus);

- Release of the superior right sagittal sinus;

- Release of the occipital sinus;

- Release of the cavernous sinus, coronary sinus and Plexus bazilar;

- Release of the ophthalmic veins.

\section{Results of the research}

After conducting the final testing we could observe that the subject $1 \mathrm{~F}$, as well as $3 \mathrm{~F}$ suffered a significant improvement of all the parameters. These two subjects have reacted positively after each treatment session. After conducting the two treatment sessions and the final testing, subject $2 \mathrm{M}$ did not show any improvement, the final parameters being the same as in the initial testing.

In the wake of the research, we can say that the hypothesis has been confirmed, because the techniques have recorded a percentage of $66,(6) \%$, in favor of improving symptoms.

Subject 1

\begin{tabular}{|c|c|c|c|}
\hline & Pain intensity & $\begin{array}{c}\text { Spurt frequency } \\
\text { within 60 days }\end{array}$ & $\begin{array}{c}\text { Intolerance to } \\
\text { noise and light }\end{array}$ \\
\hline Initial testing & 10 & 3 & 9 \\
\hline Final testing & 3 & 0 & 3 \\
\hline
\end{tabular}

Table nr. 2 - Initial testing and final testing (VAS) of the subject 1

After the data recorded and presented in table no. 2 , Subject 1 had a significant improvement of symptoms. 


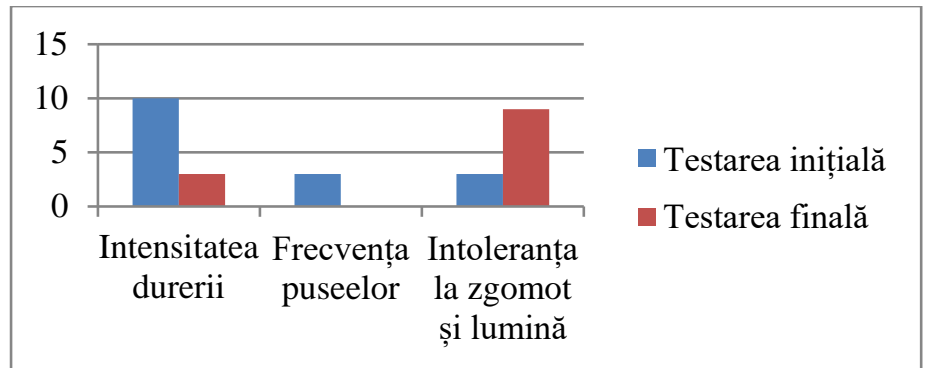

Graphic no.1.Comparing the initial and the final testing of the subject 1

Subject 2

\begin{tabular}{|l|l|l|l|}
\hline & Pain intensity & $\begin{array}{l}\text { Spurt frequency } \\
\text { within 60 days }\end{array}$ & $\begin{array}{l}\text { Intolerance to } \\
\text { noise and light }\end{array}$ \\
\hline Initial testing & 9 & 4 & 8 \\
\hline Final testing & 4 & 1 & 2 \\
\hline
\end{tabular}

Table nr. 3 - Initial testing and final testing (VAS) of the subject 2

After the data recorded and presented in table no. 3, Subject 2 had a significant improvement of symptoms.

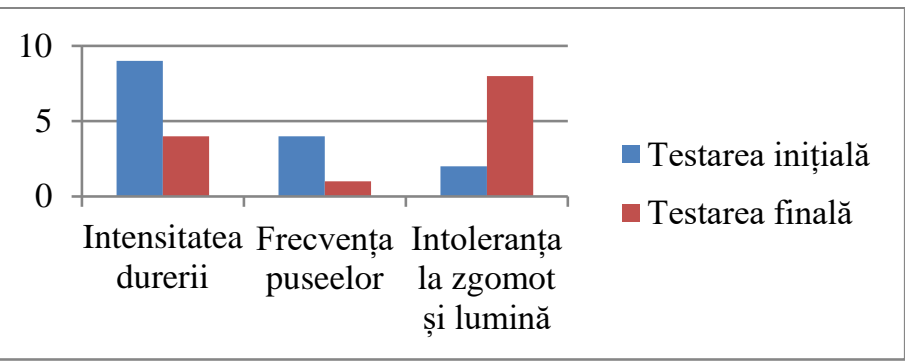

Graphic nr.2. Comparing the initial and the final testing of the subject 2

Subject 3

\begin{tabular}{|l|l|l|l|}
\hline & Pain intensity & $\begin{array}{l}\text { Spurt frequency } \\
\text { within 60 days }\end{array}$ & $\begin{array}{l}\text { Intolerance } \\
\text { noise and light }\end{array}$ \\
\hline Initial testing & 9 & 6 & 4 \\
\hline Final testing & 8 & 6 & 3 \\
\hline
\end{tabular}

Table nr. 4 - Initial testing and final testing (VAS) of the subject 3

After the data recorded and presented in table no. 4, Subject 3 didn't have any significant improvement of symptoms.

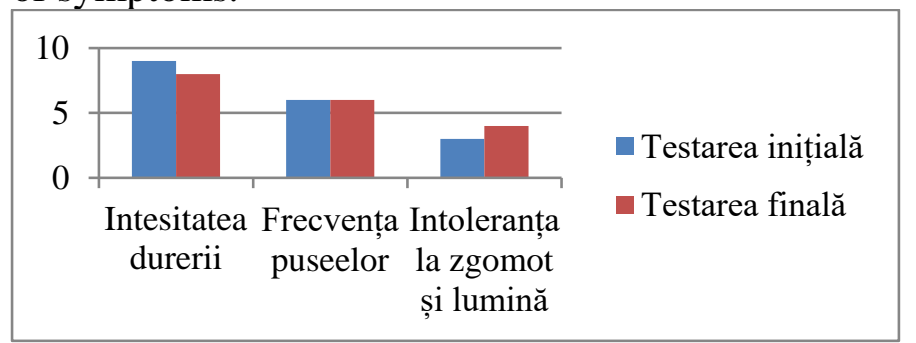

Graphic nr.3. Comparing the initial and the final testing of the subject 3

\section{Conclusions}

By analyzing the results obtained through the combination of the three treatment methods, namely the Scottish showers, hot baths $\left(37^{\circ}\right)$ and drainage techniques of venous sinuses, we've observed that patients have accepted and worked better with the therapist after the Scottish showers and the warm bath, being more relaxed and therefore, we noticed the lowering/reducing of the cephalic pain symptoms much faster due to the state of muscular and mental relaxation.

Drainage techniques of venous sinuses along with Scottish showers and warm baths $\left(37^{\circ}\right)$ had a beneficial effect in relieving symptoms caused by cephalic pain syndormes. Draining must be made by following the rules of the drainage (always towards the distal proximal).

In order to understand the drainage system, the therapist needs to have good knowledge of cranial anatomy (knowledge of the cranial bones and their sutures, craniometrical points, reciprocal tension membranes insertions) and biomechanical skull (the axes of motion of each bone).

\section{Bibliography:}

1. Alain Gehin, Atlas Kranialer Techniken - 100 Techniken in Wort und Bild, Editura URBAN\&FISCHER, Munchen, 2005;

2. A.Păunescu-Podeanu, BAZELE CLINICE PENTRU PrACTICA MEDICAL $\breve{A}$, Editura MEDICALĂ, Bucureşti 1981;

3. Frank H. Netter, MD, Atlas de Anatomie a Omului, Editura MEDICALA CALLISTO, 2008;

4. Harold Ives Magoun,OSTEOPATIA IN AMBITO CRANIALE, Editura FUTURA, 2008.

5. D’Ippolito M., Tramontano M., Buzzi M.G., Effects of Osteopathic Manipulative Therapy on Pain and Mood Disorders in Patients With High-Frequency Migraine, J. Am Osteopath Assoc., 2017, Jun 1, 117(6):265-369;

6. Schabert E., Crow W.T., Impact of osteopathic manipulative treatment on cost of care for patients with migraine headche: a retrospective review of patient records, J. Am Osteopath Assoc., 2009 Aug, 109(8):403-7;

7. Rolle G., Tremolizzo L., Somalvico F., Ferrarese C., Bressan L.C., Pilot trial of osteopathic manipulative therapy for patients with frequent episodic tension-type headache, J. Am Osteopath Assoc., 2014 Sep, 114(8):678-85

8. https://ro.wikipedia.org/wiki/Migrenă

9. https://en.wikipedia.org/wiki/Osteopathy

10. https://en.wikipedia.org/wiki/Andrew_Taylor_Still

11. http://www.osteodoc.com/ATStill.htm

12. https://en.wikipedia.org/wiki/William_Garner_Sutherland 